they lick the surface of her body and is passed on from one individual to another. This substance inhibits the worker bees from building brood cells for new queens. It also inhibits the development of eggs by laying workers. Whether this is a direct effect of the 'queen substance' on metabolism or whether the substance serves merely as a token stimulus to the central nervous system, causing the release of the appropriate hormones, has not yet been established (Butler, 1954, I956; Butler \& Simpson, I958; de Groot \& Voogd, I954).

\title{
REFERENCES
}

Brecher, G. \& Wigglesworth, V. B. (I944). Parasitology, 35, 220.

Butler, C. G. (1954), Trans. R. ent. Soc. Lond. 105, I1.

Butler, C. G. (1956). Proc. R. ent. Soc. Lond. A, 31, 12.

Butler, C. G. \& Simpson, J. (1958). Proc. R. ent. Soc. Lond. A, 33, 120.

Buxton, P. A. (1948). Parasitology, 39, I 19.

de Groot, A. P. \& Voogd, S. (1954). Experientia, ro, 384.

De Meillon, B. \& Golberg, L. (1946). Nature, Lond., 158, 269.

Dick, J. (1937). Ann. appl. Biol. 24, 762.

Englemann, F. (1957). F. Insect Physiol. I, 257.

Evans, A. C. (1935). Bull. ent. Res. 26, i 5.

Flanders, S. E. (1935). Ann. ent. Soc. Amer. 28, 438.

Glaser, R. W. (1923). F. exp. Zool. 38, 383 .

Grison, P. (I944). C. R. Acad. Sci. 219, 295.

Grison, P. (1948). C. R. Acad. Sci. 227, 1172.

Hecht, O. (1933). Arch. Schiffs-u. Tropenhyg. 37, Beiheft 3.

Hobson, R. P. (1938). Ann. appl. Biol. 25, 573.

Johansson, A. S. (I958). Nytt Mag. Zool. 7, 5 .

Kozhantshikov, I. W. (1938). Bull. ent. Res. 29, 1०3.

Mackerras, M. J. (1933). Bull. ent. Res. 24, 353.

Nayar, K. K. (1958). Proc. Indian Acad. Sci. 67, 233.

Norris, M. J. (1932). Proc, zool. Soc. Lond. p. 595.

Norris, M. J. (1933). Proc. zool. Soc. Lond. p. 903.

Norris, M. J. (1934). Proc. zool. Soc. Lond. p. 333.

Pepper, J. H. \& Hastings, E. (1943). Tech. Bull. Mont. agric. Exp. Sta. no. 413.

Reynolds, J. M. (1944). Ann. appl. Biol. 3r, 132.

Robertson, F. W. \& Sang, J. H. (1944). Proc. Roy. Soc. B, 132, 258.

Roubaud, E. (1922). Ann. Inst. Pasteur, 36, 765 .

Roubaud, E. \& Mezger, J. (1934). Bull. Soc. Pat. exot. 27, 666.

Swellengrebel, N. H. (r929). Ann. Inst. Pasteur, 43, r37o.

Thomsen, E. (1942). Vidensk. Medd. dansk naturh. Foren. Kbh. 106, 3 I9.

Trouvelot, B. \& Grison, P. (1935). C. R. Acad. Sci. 201, 1053.

Weyer, F. (r935). Z. Parasitenk. 8, 104.

Wigglesworth, V. B. (1929). Parasitology, 21, 288.

Wigglesworth, V. B. (1936a). Quart. F. micr. Sci. 79, 9 r.

Wigglesworth, V. B. (1936b). Parasitology, 28, 284 .

Woke, P. A. (1937). F. Parasit. 23, 372.

Yeoli, M. \& Mer, G. G. (1938). Trans. R. Soc. trop. Med. Hyg. 3I, 437.

\section{Nutrition and reproductive capacity in fish}

\author{
By Avril D. Woodhead, Fisheries Laboratory, Lowestoft
}

\section{Growth and fecundity}

In contrast to mammals whose growth ceases at maturity, in most fish growth continues after maturity and in some species, such as the goldfish, Carassius auratus, 
the bream, Abramis brama, and the mosquito fish, Gambusia affinis, it may be prolonged into post-reproductive life. Heape ( $193 \mathrm{I}$ ) has suggested that growth and reproduction are alternative activities in fish; thus the majority of fish show a seasonal decline in growth at the onset of maturation, the extent of which varies between species and often between the sexes.

The fecundity of fish increases with increasing length, and in some species at a greater rate than body-weight, so that in older, larger fish the reproductive strain may impose a limit to increasing egg production (Gurking, 1959). Orton (I929) has suggested that overproduction of eggs may so exhaust older fish as to predispose them to death from sublethal environmental hazards, and Beverton \& Holt (I959), reviewing longevity in fish, also concluded that natural mortality was closely related to reproductive strain.

\section{Nutritional drain of maturation and migration}

Despite the extra nutritional requirements, many fish cease to feed during gonadal maturation (Homans \& Vladykov, I954), and in the salmon and the herring degenerative changes occur in the gut (Rutter, I902; Greene, 1926). During this period of semi-starvation the fish may carry out a lengthy migration, prominent sexual characters may be developed (Davidson, 1935), or a profound metamorphosis may precede maturation (Okkelberg, I92 I); these factors are a further nutritional drain.

Fat and protein reserves are withdrawn from the muscles and the liver during maturation. Greene (1926) found that the migrating king salmon, Oncorhyncus tschawytscha, lost $5 \mathrm{I} \cdot 6 \%$ of the total muscle mass; the fat content of the muscle fell from ${ }_{15} 5$ to $2 \cdot 2 \%$ at spawning and the protein content from 17 to $13.7 \%$; similar changes occur in other fish; thus the oil content falls from 23 to $10 \%$ in the maturing North Sea herring, Clupea harengus (Wood, I958), and from I 4 to $7 \%$ in the mackerel, Scomber scombrus (Lühmann, 1956). Changes also occur in the amino-acid composition of the flesh proteins and in the ionic and protein contents of the blood.

Table I. Composition of fish gonads (from Braekkan \& Probst, I953)

\begin{tabular}{|c|c|c|c|c|c|c|c|c|c|c|}
\hline Species & $\begin{array}{c}\text { Weight } \\
(\mathrm{g})\end{array}$ & $\underset{\substack{\text { Dratter } \\
(\%)}}{\stackrel{0}{0})}$ & $\begin{array}{l}\text { Fat } \\
(\%)\end{array}$ & $\begin{array}{l}\text { Ash } \\
(\%)\end{array}$ & $\begin{array}{c}\text { Protein } \\
(\mathbf{N} \times 6: 25) \\
(\%)\end{array}$ & $\begin{array}{c}\text { Nicotinic } \\
\text { acid } \\
(\mu g / g)\end{array}$ & $\begin{array}{c}\text { Riboflavin } \\
(\mu \mathrm{g} / \mathrm{g})\end{array}$ & $\begin{array}{l}\text { Pantothenic } \\
\text { acid } \\
(\mu g / g)\end{array}$ & $\underset{(\mu \mathrm{g} / \mathrm{g})}{\operatorname{Vitamin}} B_{12}$ & $\underset{\text { (i.u. } / \mathrm{g})}{\text { Vitamin }} A$ \\
\hline $\begin{array}{l}\text { Herring, } \\
\text { Clupea } \\
\text { harengus: }\end{array}$ & & & & & & & & & & \\
\hline Male & 46 & 34.3 & $4 \circ$ & $I^{\prime} 4$ & $20 \cdot 2$ & 143 & $2 \cdot 6$ & 143 & $0.1 x$ & I. 5 \\
\hline $\begin{array}{l}\text { Female } \\
\text { Mackerel, } \\
\text { Scomber } \\
\text { scombrus: }\end{array}$ & 45 & 29 & $5 \cdot 1$ & $3 \cdot 8$ & $22 \cdot 7$ & $18 \cdot 8$ & $1 \cdot 7$ & 14 & 0.07 & - \\
\hline $\begin{array}{l}\text { Male } \\
\text { Female }\end{array}$ & $\begin{array}{l}44 \\
55\end{array}$ & $\begin{array}{l}34 \cdot 2 \\
29 \cdot 4\end{array}$ & $\begin{array}{l}7 \cdot 2 \\
1 \cdot 6\end{array}$ & $\begin{array}{l}\mathbf{I} \cdot 7 \\
\mathbf{2} \cdot \mathbf{I}\end{array}$ & $\begin{array}{l}24.0 \\
16.7\end{array}$ & $\begin{array}{l}\mathbf{2 2} \\
\mathbf{2 1}\end{array}$ & $\begin{array}{l}9 \cdot 2 \\
2 \cdot 2\end{array}$ & ${ }_{11}^{46} \cdot 8$ & $\begin{array}{l}0.30 \\
0.07\end{array}$ & $\underline{5 \cdot 0}$ \\
\hline
\end{tabular}

The results of some detailed analyses of ripe fish gonads are given in Table $\mathrm{I}$. A number of changes occur in the composition of the ovary during the process of maturation; there is an increase in the percentage protein content and dry matter (Garrod \& Newell, 1958; Braekkan, 1958), and a preferential accumulation of the more unsaturated fatty acids (Channon \& El Saby, 1932; Shorland, 1939). A high content of carotenoids has been demonstrated in the maturing ovaries of several 
species of fish (Goodwin, 1950); P. A. Plack (personal communication) has found an increase in the total content of carotenoids and vitamin $A$ aldehyde in the ripening ovaries of the cod, but a fairly steady level of vitamin A ester and alcohol. Junker (1952) has shown that whereas the vitamin A contents of the ovaries of the herring and the carp increase during maturation, it falls in the ripening testes. There is also a marked decrease in the pantothenic-acid content of maturing cod ovaries, and a lesser decrease in vitamin $B_{12}$, but no change in the levels of riboflavin and nicotinic acid (Braekkan, 1958).

\section{Variations in reproductive capacity with feeding}

Feeding and the rate of growth affect the onset of first maturity, the fastestgrowing fish maturing earliest (Raitt, 1932; Simpson, 1951; Alm, 1953). An improvement in feeding has been shown to hasten the onset of maturity by I year in flounders, Pleuronectes limanda (Kändler, 1932; Gross, 1949), herring, Clupea harengus (Cushing \& Burd, 1956) and char, Salvelinus alpinus (Runnström, 1951), whereas poor feeding delayed maturity in trout and perch, Perca fluviatilis (McCay, Dilley \& Crowell, I928-9; Alm, 1953). In a laboratory population Svärdson (1943) found that maturity occurred earliest in fastest-growing Lebistes; fish of medium growth rate matured later but at a larger size and with a larger gonad, and the slowestgrowing fish were last to mature, again at a small size, and with a small gonad (Fig. r).

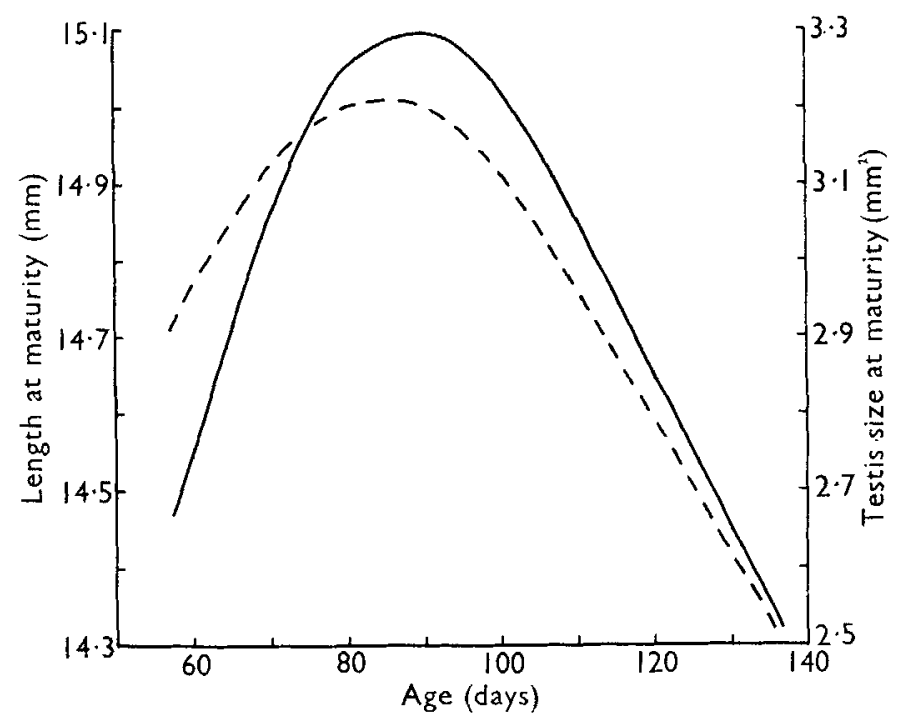

Fig. I. Length of body and size of testis in relation to age at maturity in Lebistes (after Svärdson, 1943). - , body length; - ... - testis size.

However, in overcrowded natural conditions with very little food available for growth, stunted populations are found in which maturity occurs very early and at a small size (Alm, 1946). In Lebistes, Svärdson (1943) found that, after the testes had 
attained a certain size, spermiogenesis was most rapid when the food supply was poor and he concluded (Svärdson, I95I) that this fact might account for precocious maturation in stunted populations. However, precocious maturation has never been induced by a poor diet in differential feeding experiments with a single stock of fish, and it seems likely that earlier maturation in conditions of overcrowding would have a selective advantage when growth is very slow.

The fecundity of fish may increase with better feeding; thus Simpson (195 I) found that in the North Sea fast-growing plaice, Pleuronectes platessa, from good feeding areas had a higher fecundity than slower-growing fish of the same size from poor areas. When fishing reduced the numbers of the Sakhalin herring, feeding conditions improved considerably and their fecundity increased (Piskunov, 1952); similarly the fecundity of Caspian roach, Rutilus rutilus, of I $8 \mathrm{~cm}$ length increased by $50 \%$ in 1946 when feeding conditions were exceptionally favourable (Chugunova, I95I). In the viviparous mosquito fish, Gambusia affinis, the brood size also increases with better feeding (Krumholz, 1948). A considerable number of eggs do not develop fully in carp, Cyprinus carpio, but are resorbed after spawning (up to $35 \%$ of the eggs in older fish), and Vasnetzov (quoted by Nikolsky, 1950) has suggested that when there is a substantial improvement in feeding conditions these eggs may develop normally, increasing fecundity. In at least some species egg size may be affected by feeding. Comparing different populations of char, Salvelinus alpinus, and of whitefish, Coregonus clupeaformis, in Swedish lakes, Määr (1949) and Toots (I95I) found that populations with a high growth rate produced eggs of a large size; Määr (I950) and Nikolsky (I950) have also reported that within the same population of fish the larger fish have eggs of a larger size.

The level of feeding may influence spawning frequency in fish, thus Gambusia females kept well fed in the laboratory produce broods with greater frequency than when wild (Turner, 1937). In Salvelinus fontinalis and S. alpinus a deficient diet, due to overcrowding, may prevent annual spawning (Vladykov, 1956; Grainger, 1953) and in the Great Slave Lake whitefish, Coregonus clupeaformis, with a very short growing season of 3 months, spawning may occur at intervals of 2 years or more instead of annually (Kennedy, 1953).

Very few studies have been made on the role of specific nutritional requirements in reproduction; however, an interesting beginning has been made by Hubbs \& Stavenhagen (1958) who showed that when female green throat darters, Etheostoma lepidum, were given a diet deficient in vitamin A and carotenoids their eggs and larvae had a very reduced survival time; addition of vitamin $A$ to the diet produced viable offspring. Further experiments of this type should be most valuable.

\section{Viviparity}

All stages from ovoparity through ovoviviparity to complete placental viviparity are found in both teleostean and elasmobranch fishes, and the morphological modifications of both parent and embryo have been reviewed in detail (Budker, 1958; Bertin, I958). With the non-placental livebearers, in such species as the elasmobranch, Acanthias vulgaris, and the teleost, Sebastes marinus, the embryo derives 
only protection from the parent, and during development the dry weight of the egg falls, indicating little maternal contribution, the embryo living on the contents of its yolk sac; in other species (e.g. Trygon violacea, Zoarces viviparus) the embryo is greatly dependent upon the maternal organism for food supply, the uterine fluid is rich in nutrients and the dry weight of the embryo increases during development. Between these two extremes are all stages of increasing dependence of the embryo on the mother. In elasmobranchs Ranzi (1937) has correlated the degree of dependence of the egg with the nature of the uterine fluid, the modifications of the uterine wall and the reduction in liver size during pregnancy. However, in Mustelus laevis, in which a functional placenta is developed and the conditions of pregnancy approach those in higher mammals, the liver size increases during the later stages of pregnancy, and Ranzi suggested that as a method of nutrition the placenta is more economical than ovoviviparity.

\section{REFERENCES}

Alm, G. (1946). Medd. UndersöknAnst. Sötvattensfisk. Stockh. 25, т.

Alm, G. (1953). Rep. Inst. Freshw. Res. Drottning. 35, II.

Bertin, L. (1958). Traité de Zoologie, r3, 1791. Paris: Masson et Cie.

Beverton, R. H. J. \& Holt, S. J. (1959). Ciba Found. Colloq. Ageing, 5, 142.

Braekkan, O. R. (1958). Fiskeridir. Skr. Tek. undersøk. 3, no. 7, p. I.

Braekkan, O. R. \& Probst, A. (I953). Fiskeridir. Skr. Tek. undersøk. 2, no. 13, p. I.

Budker, P. (1958). Traité de Zoologie, 13, 1755. Paris: Masson et Cie.

Channon, H. I. \& El Saby, M. K. (I932). Biochem. F. 26, 202 I.

Charles, E. (1931-2). Quart. F. exp. Physiol. 21, 81.

Chugunova, N. I. (1951). Trans. Inst. Mar. Fish. U.S.S.R. 18.

Cushing, D. H. \& Burd, A. C. (1956). Nature, Lond., 178, 86.

Davidson, F. A. (1935). F. Morph. 57, 169.

Garrod, D. J. \& Newell, B. S. (1958). Nature, Lond., 181, I +1 I.

Gurking, S. D. (1959). Ciba Found. Colloq. Ageing, 5, I81.

Goodwin, T. W. (1950). Biol. Rev. 25, 391.

Grainger, E. H. (1953). J. Fish. Res. Bd Can. ro, 326.

Greene, C. W. (1926). Physiol. Rev. 6, 201.

Gross, F. (1949). F. Mar. biol. Ass. U.K. 28, I.

Heape, W. (1931). Emigration, Migration and Nomadism. Cambridge: W. Heffer and Sons.

Homans, R. E. S. \& Vladykov, V. D. (1954). F. Fish. Res. Bd Can. I1, 535.

Hubbs, C. \& Stavenhagen, L. (1958). Physiol. Zoöl. 31, 280.

Junker, M. (1952). Arch. Fischwiss. 4, 19.

Kändler, K. (1932). Rapp. Cons. Explor. Mer, 78, I.

Kennedy, W. A. (1953). F. Fish. Res. Bd Can. Io, 413.

Krumholz, L. A. (1948). Ecol. Monogr. 18, 1.

Lühmann, M. (1956). Arch. Fischwiss. 7, 61.

Määr, A. (1949). Rep. Inst. Freshw. Res. Drottning. 29, 57.

Määr, A. (1950). Rep. Inst. Freshw. Res. Drottning. 3r, 127.

McCay, C. M., Dilley, W. E. \& Crowell, M. F. (1928-9). F. Nutr. I, 233.

Nikolsky, G. V. (1950). Zool. Zh. 29, 489.

Okkelberg, P. (192 I). f. Morph. 35, I.

Orton, J. H. (1929). Nature, Lond., r23, I4.

Piskunov, I. A. (1952). Zool. Zh. 31, I.

Ranzi, S. (1937). Arch. Zool. (ital.), Napoli, 24, 169.

Raitt, D. S. ( I932). Fisheries Scotland, sci. Invest. no. I, p. I.

Runnström, S. (1951). Rep. Inst. Freshw. Res. Drottning. 32, 66.

Rutter, C. (1902). Bull. U.S. Fish Comm. 22, 65.

Shorland, F. B. (1939). Biochem. F. 33, 1935.

Simpson, A. C. (1951). Fish. Invest., Lond., Ser. 2, 17, no. 5, p. 27.

Svärdson, G. (1943). Medd. UndersöknAnst. Sötvattenfisk. Stockh. 21, I.

Svärdson, G. (1951). Rep. Inst. Freshw. Res. Drottning. 31, I 27. 
Toots, H. (195 I). Rep. Inst. Freshw. Res. Drottning. 32, 133.

Turner, C. L. (1937). Biol. Bull. 72, I 45.

Vladykov, V. D. (1956). F. Fish. Res. Bd Can. 13, 799.

Wood, R. J. (1958). F. Cons. int. Explor. Mer, 23, 390.

\section{Nutrition and reproduction in the domestic fowl}

\section{By L. G. Chuвв, Houghton Poultry Research Station, Houghton, Huntingdonshire}

In the domestic fowl (Gallus domesticus) the fertilized egg in the infundibulum of the oviduct consists of an enormous mass of yolk about $40 \mathrm{~mm}$ in diameter on which rests the blastodisc about $3 \mathrm{~mm}$ in length. The whole is enclosed by a vitelline membrane, but as the egg passes down the oviduct (a process requiring about $24 \mathrm{~h}$ ) albumen is deposited around it, shell membranes are laid down enclosing the albumen and, finally, calcium salts are deposited on them. This macrolecithal egg provides a readily assimilable food supply for the extremely rapid extragenital development of the embryo. If certain nutrients are lacking or are present in insufficient amounts, death or morphological abnormalities may occur.

Several excellent reviews have been published on both the qualitative and quantitative nutritional requirements of breeding fowls for the maintenance of a high reproductive performance (Cruickshank, I940-I; Taylor, 1949; Landauer, I95 I ; Bolton, I958) and I therefore propose to discuss some of the effects of individual nutritional deficiencies on embryonic development, with special emphasis on the age at death of the embryo and the occurrence of specific abnormalities.

\section{Nutrition and fertility in the male}

Knowledge of the effect of specific nutrients on fertility in the male is extremely limited. Vitamin A deficiency results in a reduction in comb size, underdeveloped testes, a decrease in sperm concentration and motility, and an increase in abnormal sperms (Craft, M'Elroy \& Penquite, 1926; Burrows \& 'Titus, r938; Garcia \& Paredes, I957; Lowe, Morton, Cunningham \& Vernon, I957).

Adamstone \& Card (1934) investigated the effect of a practical-type diet in which vitamin $\mathrm{E}$ had been destroyed by ethereal ferric chloride and found that by the end of the 2nd year some birds had become sterile and showed degenerative changes in the testes. Recently, Lorentz, Abbott, Asmundson, Adler, Kratzer, Ogasawara \& Carson (1959) reported that male chickens maintained for 2 months on a purified diet deficient solely in vitamin $\mathrm{E}$ showed reduced testis size and degenerative changes in the seminiferous tubules.

There is no conclusive evidence available that nutritional deficiencies in the diet of the male influence the embryonic development and hatchability of eggs fertilized by him. The paucity of available information in this field suggests that further research is required. 